\title{
Devaluation and Competitiveness: Evidence from the Tea and Cotton Textiles Industries
}

\author{
Basudeb Guha-Khasnobis* \\ Indira Gandhi Institute of Development Research
}

\begin{abstract}
This paper measures the effect of currency rate changes on the competitive ness of I ndia's main export industries, Tea and Cotton Textiles. In contrast to the conventional approach that uses data from commodity markets, the present study is based on data from stock markets. The analysis is done in two parts. The first part reports estimates of somewhat si gnificant currency rate exposure of the major Tea and Cotton Textiles exporting firms in India and other coun tries. The second part reports the movements of the average excess returns of the exposed Indian firms, based on an event-study of the devaluation of the Rupee in 1991. The theory behind the econometric model s invokes only the effi ciency property of financial markets and seems less controversial than its coun terpart in the conventional approach. (JEL Classification: F0)
\end{abstract}

\section{Introduction}

A common method for measuring the effect of a currency devaluation on the competitiveness and export performance of home goods is to estimate

* Correspondence Address: Indira Gandhi Institute of D evelopment Research, General A.K. Vaidya M arg, Goregaon (E), Bombay 400 065, India; This article comes from a chapter of my Ph.D. dissertation at the University of Rochester. The comments of Ronald Jones, Alan Stockman and Jeremy Greenwood were very helpful. I am grateful to the anonymous referees of this journal for some invaluable suggestions. All errors are mine.

(C1997 - Institute for International Economics, Sejong Institution. All rights reserved. 
an equation of the trade balance and generate a measure of abnormal behaviour following the devaluation. If this abnormal or residual factor turns out to be positive it is claimed that a devaluation has been successful in improving the trade balance. ${ }^{1}$ The literature is weighted with evidence from commodity markets, based on trade flows and commodity prices, to the neglect of possible evidence from stock markets. One reason behind it may be the fact that devaluations are a hallmark of less developed countries where stock markets are still in their infancies. However, in recent years many of these stock markets have attained maturity, especially with the onset of economic liberalization in these countries. The Indian stock market is an example. Although they have been in existence for more than a century, the major stock markets in India started gathering momentum only since the beginning of reforms in the mid ' 80 's and were found in full swing after the formal abolition of the repressive economic regime of the country in 1991.

One may have at least two quarrels with the prevailing method of measuring cur rency rate effects on competitiveness using commodity market variables. First, most commodity market variables such as prices and traded quantities do not adjust instantaneously but with lags of unknown structures. Thus, it is difficult to relate changes in exchange rates with changes in trade flows. The correlation, if any, may be purely coincidental. Financial market variables such as stock prices respond more quickly to the same changes, making a presumed relationship between exchange rates and stock prices less suspect. Second, even if adjustments are to be made for the lagged response of trade flows, it seems impossible to identify correctly the lag structures of the hundreds of items that comprise the trade balance of a country. Thus, the use of a favourable trade balance as the comprehensive measure of enhanced competitiveness due to currency depreciations, is riddled with problems. An alternative is to try and measure the effect of currency depreciations on the competitiveness of individual industries. In this paper, I have tried to measure the effect of currency rate changes and the devaluation of the Rupee [1991] on the valuation of Cotton Textiles and Tea

1. M iles [1978] enumerates a number of such studies conducted over the past several decades in many different countries. 
exporting firms from India as well as their main international rivals. ${ }^{2}$

The paper is organized as follows. In Section II. A, I will discuss some of the theoretical arguments that link devaluations with the trade balance and provide the basis for the conventional approach stated above. In Section II. B some of the literature on currency rate exposures of firms that is directly relevant to the present analysis is reviewed. This literature forms the basis of the alternative approach used here. Section III presents the econometric model and reports the results on currency rate responses of firms from the main exporting countries in the Tea and Textiles industries. An event study on the Indian devaluation in 1991 is conducted in Section IV. A summary and the scope for extending the present analysis comprise Section V.

\section{Devaluation and the Trade Balance}

\section{A. Reallocation of Domestic Factors of Production}

The relationship between the trade balance and the nominal exchange rate has been explored extensively in a particular strand of literature in the theory of International Trade. The essential argument there is as follows. In a small open economy, a devaluation raises the domestic relative price of traded vs non-traded goods which in turn reallocates consumption away from the traded goods and factors of production into the traded goods sectors. Thus, the trade balance improves. The reason why the domestic relative price changes at all due to a devaluation (which, essentially, is a change in the numeraire) lies in the short run stickiness of one or more nominal prices (such as the wage rate) in the economy. The theme of non-flexible prices and the consequent effect of a devaluation on the trade balance has been discussed by various authors. The role of factor-intensities as well as the elasticities of factor substitutions are crucial in determining the fate of the relative price of traded vs non-traded goods. Jones \& Corden [1976] argue that if tradeables are capital intensive, a devaluation will increase the domestic relative price of traded vs non-traded goods and improve the trade

2. The alternative method based on stock prices has been used by Luehrman [1991] in order to study the effects of currency depreciations on the world Auto and Iron and Steel industries. 
balance if nominal wages are held constant. Acharyya [1994] proves that even if the Jones-Corden condition is satisfied, a devaluation may worsen the trade balance if there is an imported input. Guha-Khasnobis [ 1995, 1996] decomposes tradeables into importables and exportables and argues that if the latter comprise mainly traditional items produced chiefly with unskilled labor, a devaluation will reduce the relative price of traded vs nontraded goods and lead to a perverse outcome on the balance of trade if unskilled wages tend to be rigid in the short run. It is also shown that if there exists an infrastructure bottleneck, a devaluation may backfire. Thus, the emphasis of this literature is not so much on the competitiveness of individual firms or industries. Rather, it relies on the possibility of a reallocation of domestic resources amongst different sectors of production that may bring about the desired positive effect on the aggregate trade balance of a country. In the same vein, the conventional method of empirical analysis also looks at possible improvement in the trade balance due to a devaluation. Price inflexibilities that in conjunction with the structure of production decide the outcome of a devaluation are context-specific. Hence, it seems impossible to arrive at a general theory about the effect of a devaluation on the trade balance. This casts further doubts on the existing empirical method outlined earlier and is reiterated by some inconclusive findings by Edwards [1991].

\section{B. Currency Depreciations and the Individual Firm}

A parallel strand of literature examines the fate of a firm due to currency depreciations. It is common to hear arguments in the media that a cheaper currency increases competitiveness of exporting firms (and hence, improves the trade balance). The dependence of the firm on currency rate changes is known as exposure. In a seminal paper Adler and Dumas [1986] show how exposure may be looked at from the viewpoint of stockholders and analysts, can be identified as a statistical quantity, and, measured by regression coefficients rather than projected accounting figures. Jorion [1990] lends support to this theory by suggesting that without presuming any causal link, exposure measures the sensitivity of the value of the firm to exchange rate randomness and can be measured by the regression coeffi- 
cient of the change in the value of the firm on the change in the exchange rate. On the basis of an empirical analysis, J orion concludes that the greater the weight of exports in a company's sales, the greater is the response of stock prices to exchange rate changes. Amihud [1994] finds that large, in an absolute sense, U.S. exporting firms are not significantly affected by exchange rate changes. The finding prevails for those firms which have a relatively larger share of exports in their total sales as well. Exposure is insignificant for contemporaneous, lagged as well as unanticipated exchange rate changes. One possible explanation is successful hedging by such firms. However, Adler \& Simon [1986] indicate that hedging possibilities are restricted by the availability of the set of contracts in the financial market. Levi [1994] develops analytical models that show how exchange rates can affect the value of a firm by influencing operating income or corporate profits. The sensitivity of the value of the firm on exchange rate changes is shown to depend on the elasticity of demand as well as profit margins abroad and the net asset position denominated in currencies other than domestic. Levi emphasizes the inherent volatility of exposure as an important reason why its estimated measure is likely to be statistically insignificant.

\section{Sensitivity of Indian Export-firms in Tea and Textiles Industries}

The econometric framework employed in this section draws on the theoretical developments outlined in Section II. B. The argument that currency depreciations and devaluations enhance competitiveness does not make sense if the revenues in any given industry are purely contractual. Therefore, the method used here rests on the assumption that revenues are con testable. That is, firms from different countries compete to get a share of the scarce revenues in the industry in question. The method invokes the intrinsic property of stock markets. Formed by portfolio choices by a population of forward-looking investors, stock prices are expected to reflect instantaneously all the future effects of any current change on the fate of the exposed firm. If currency depreciations were to enhance competitiveness, the exporting firm must be able to wrest a larger share of total industry revenues. Assuming that total industry revenues remain constant due to depre- 
ciations in any one country, it implies that there will be a redistribution of the same in favor of the exporting firms in the depreciating country. Any redistribution of revenues must map itself onto a relative increase in equity value of the firm in an efficient financial market. This proposition is tested in this section for the Cotton Textiles and the Tea industries, India's major exports.

I denote the proportion of the ith firm's equity value to total industry value as:

$$
\mathrm{S}_{\mathrm{i}}=\mathrm{V}_{\mathrm{i}} / \mathrm{V}
$$

for $\mathrm{i}=1, \ldots, \mathrm{n}$, where $\mathrm{n}$ is the number of firms for that product in the global market, and, $V=\sum_{i} . v_{i}$. The equity value of the individual firm, $v_{i}$, on a given trading day equals the product of the number of outstanding shares and the price of each share. The derivative of $s_{i}$ with respect to the nominal exchange rate $E$ will gives the response of the equity value share of the firm to a change in the exchange rate. Differentiation of the above equation with respect to the nominal exchange rate yields the following:

$$
d v_{i} / d E=V\left(d s_{i} / d E\right)+s_{i}(d V / d E)
$$

Only the first term represents the competitiveness effect: it shows the extra share the i-th firm is able wrest from its rivals. Since $V$ is always positive for an industry, the competitiveness effect has the same sign as $\mathrm{ds} / \mathrm{dE}$. This term may be estimated from a linear regression, assuming that for small changes in the exchange rate, the relationship is approximately linear. The following equation in logarithms is estimated for each firm:

$$
\log \left(s_{i, t+1} / s_{i, t}\right)=\alpha+\beta\left[\log \left(E_{t+1} / E_{t}\right)\right]+\varepsilon_{i, t}
$$

where $s_{i}$ denotes the equity value of the $i$-th firm in the industry, and, $E_{j}$ denote the bilateral exchange rate between the j-th country and the U.S.A. rise in $E_{j}$ denotes an appreciation of the $j$-th currency against the dollar. The hypothesis that competitiveness is unaffected by exchange rate changes implies that $\beta=0$.

In order to get a clearer picture at the individual firm level, the shares of the individual firms' equities are replaced with simple equity values. Obviously, the pattern of change in equity values will imply the corresponding 
changes in the shares not only on an overall industry basis, but on a bilateral basis as well. That is, if we note that the equity value of, say, firm A has gone up, due to a change in the bilateral rate, say, a, and those of, say, firms $B$ and $C$ have gone down due to the same change in a, we can conclude that the change in a has resulted in a redistribution of industry share from firms $B$ and $C$ to firm $A$.

Stock prices for the Indian firms were obtained from three major daily newspapers, The Hindu, The Economic Times and The Indian Express, published out of Madras. Bombay and New Delhi respectively. There are over 50 incorporated firms engaged in the production and sales of tea. The first screening involves removing those firms that are diversified in unrelated products. Second only those firms that are specialized more in the sales and export of tea rather than production are chosen. Third attention is restricted to the four largest firms according to the value of their equity as of the financial year ending February 1989. The financial statements of these firms are obtained from Kothari's Industrial Directory for India. Similar selection method is applied for the Textile industry. The three major firms that dominate the production and sale of tea in Kenya are Brooke B ond Kenya Ltd., Kakuzi and George Williamson. Their stock prices, quoted at the Nairobi Stock Exchange, are listed daily on the business section of the English daily out of Nairobi called Daily Nation. Stock prices for the U.K. based firms are obtained from The Financial Times of London while those of the Japanese firms are obtained from the Dow J ones database known as Tradeline. Stock prices of tea exporting firms from Sri Lanka are not available. However, I have included the Sri Lankan currency exchange rate vis a vis the dollar in the equations in order to see if changes in that have any discernible effect on the firms from the other countries. Daily exchange rates, also obtained from Tradeline, represent the average of the day's closing selling and buying rates. Stock prices for the textile exporting firms from Thailand, Hong Kong and Taiwan are obtained from the Daily Asian Wall Street J ournal.

The period covered in the study is the calender year 1991. M ultiplying the daily stock price of each firm by the number of outstanding shares on each day, the "equity value" for each firm is obtained. The results for individual firms are reported in the Tables 1 and 2. In these two tables, the rows 


\section{Table 1}

\section{Exposure of Firms in Tea Industry}

\begin{tabular}{|c|c|c|c|c|c|c|c|c|}
\hline \multirow{2}{*}{ Country } & \multirow{2}{*}{ Firm } & \multicolumn{5}{|c|}{ Exchange Rates } & \multirow{2}{*}{ DW } & \multirow{2}{*}{ F-Stat } \\
\hline & & India & Kenya & Japan & U.K. & Sri lanka & & \\
\hline \multirow{4}{*}{ India } & Tata Tea & $.07(.054)$ & $-.07(-.25)$ & $-.06(-.32)$ & $.27(1.28)$ & . $42(1.02)$ & 1.91 & 1.38 \\
\hline & Lipton & $.05(.57)$ & $-.34(-.25)$ & $-.22(-.78)$ & $.59(.68)$ & $.73(1.75)$ & 1.98 & 1.32 \\
\hline & Assam Tea & $-.01(-.08)$ & $-.46(-1.93)$ & $-.23(-1.16)$ & $.32(1.51)$ & $-.31(-.75)$ & 2.00 & 1.33 \\
\hline & Brooke Bond (I) & $-.15(-1.71)$ & $.08(.40)$ & $.42(2.04)$ & $-.34(-1.37)$ & $.42(1.05)$ & 2.05 & 2.14 \\
\hline \multirow{3}{*}{ Kenya } & Brooke Bond $(\mathrm{K})$ & $.38(2.27)$ & $-.64(-1.31)$ & $.05(.18)$ & $.28(.72)$ & $1.02(1.63)$ & 2.06 & 2.20 \\
\hline & George Williams & $-.08(-1.09)$ & $-.12(-.24)$ & $.44(1.43)$ & $.37(.80)$ & $.54(1.4)$ & 1.90 & 1.41 \\
\hline & Kakuzi & $.17(1.26)$ & $-.19(-.51)$ & $.04(.16)$ & $-.21(-.64)$ & $.36(.70)$ & 1.93 & 1.39 \\
\hline \multirow{2}{*}{ Japan } & Pokka Corp. & $.42(2.61)$ & $.51(1.61)$ & $-.27(-1.17)$ & $-.33(-1.36)$ & $-.23(-.48)$ & 2.01 & 1.68 \\
\hline & Ishigaki & $.54(2.13)$ & $-.07(-.14)$ & $.19(.50)$ & $.22(.57)$ & $-.91(-1.20)$ & 2.03 & 1.66 \\
\hline \multirow{2}{*}{ U.K. } & Moran & $.009(.26)$ & $-.08(-.76)$ & $.06(.40)$ & $.20(1.52)$ & $.03(.16)$ & 2.07 & 1.29 \\
\hline & Williamson & $-.006(-.18)$ & $-.06(-.33)$ & $.13(.66)$ & $.06(.42)$ & $.04(.12)$ & 1.82 & 1.18 \\
\hline
\end{tabular}

denote the individual firms. The columns represent the bilateral exchange rates vis a vis the U.S. dollar. For example, the column "India" represents the variable "dollars per rupee" and so on. If our theoretical presumption is correct, we shall expect a statistically significant negative coefficient in the cells (firm of country A, currency of country A), and positive other wise.

$\mathrm{Next}$, for each country, individual firm equity values are aggregated in order to obtain a national measure of competitiveness. The log of the percentage change (between two successive periods) of these shares are then regressed on the bilateral exchange rates with respect to the dollar. B esides exchange rates, there are other important explanatory variables, not included in the analysis, that affect these equity shares. For example, there may be changes in the pattern of world demand for tea, or, changes in the prices of related products such as coffee. These omitted variables will affect the residuals from the regressions performed above. Depending on the nature of the omitted variables, it is possible that the residuals from each of the regressions are related to each other. In order to take into account such cross-equation correlation of residuals and in improving the efficiency of the estimates, we perform a stacked regression, taking all the countries together in each industry. Tables 3 and 4 report these results. 


\section{A. Discussion of Results}

From Table 1, in the Tea industry, B rook B ond, India gains significantly due to depreciation of the rupee. It is also hurt by a depreciation of the yen. Lipton, India is hurt by depreciations of the British pound and the Sri Lankan rupee. Brook Bond, Kenya is hurt by depreciations of the Indian and Sri Lankan cur rencies. Both Pokka and Ishigaki, the Japanese firms are strongly hurt by depreciation of the rupee. Pokka is also adversely affected by depreciation of the Kenyan shilling. From Table 2 , in the Textile industry, Bombay Dyeing and Reliance the leading exporters of cotton textiles from India gain significantly from a depreciation of the rupee against the dollar. The coefficients for all the other firms are negative but not highly sig-

\section{Table 2}

\section{Exposure of Firms in the Textile Industry}

\begin{tabular}{|c|c|c|c|c|c|c|c|c|}
\hline \multirow{2}{*}{ Country } & \multirow{2}{*}{ Firm } & \multicolumn{5}{|c|}{ Exchange Rates } & \multirow{2}{*}{ DW } & \multirow{2}{*}{ F-Stat } \\
\hline & & India & Pakistan & Thailand & Taiwan & Hong Kong & & \\
\hline \multirow{4}{*}{ India } & Bombay Dyeing & $-.04(-2.52)$ & $-.01(-.34)$ & $-1.04(-.87)$ & $.02(.07)$ & $-.84(-.29)$ & 1.99 & 1.61 \\
\hline & DCM & $-.51(-.48)$ & $0(.34)$ & $-.75(-.97)$ & $-.98(-.73)$ & $.82(.45)$ & 2.03 & 1.3 \\
\hline & Century & $-.08(-.37)$ & $0(0)$ & $.83(.51)$ & $.65(2.31)$ & $-.64(-1.66)$ & 2.00 & 2.88 \\
\hline & Reliance & $-.07(-2.23)$ & $0(0)$ & $-1.99(-1.13)$ & $.18(.59)$ & $.22(.52)$ & 1.99 & 1.84 \\
\hline \multirow{3}{*}{ Pakistan } & Dewan Textile & $.01(.18)$ & $0(0)$ & $-.13(-.20)$ & $.05(.44)$ & $-.41(-.27)$ & 2.23 & 0.71 \\
\hline & Dewood & $-.05(-.52)$ & $0(0)$ & $0(.01)$ & $.12(.92)$ & $-.26(-.14)$ & 2.18 & 1.03 \\
\hline & Crescent & $.009(.01)$ & $0(0)$ & $.06(.09)$ & $-.08(-.69)$ & $-.62(-.36)$ & 2.17 & 0.84 \\
\hline \multirow{3}{*}{ Thailand } & Thaitex & $.41(1.84)$ & $0(0)$ & $-3.38(-2.08)$ & $-.38(-1.32)$ & $3.17(81)$ & 2.02 & 1.71 \\
\hline & TRT & $.17(.65)$ & $0(0)$ & $-3.73(-1.92)$ & $.04(.12)$ & $.78(.17)$ & 1.91 & 1.64 \\
\hline & Lucky Textitle & $.05(.31)$ & $0(0)$ & $-.95(-.74)$ & $-.06(-.26)$ & 3.34 (1.08) & 1.93 & 1.12 \\
\hline \multirow{3}{*}{ Taiwan } & Carnival & $-.04(-.16)$ & $0(-.91)$ & $-1.48(-.79)$ & $-.98(-2.98)$ & $.04(.008)$ & 1.90 & 2.21 \\
\hline & Rebar & $-.04(-.17)$ & $-.01(-1.67)$ & $-.54(-.35)$ & $-.66(-2.41)$ & $2.18(.58)$ & 1.89 & 2.43 \\
\hline & Chung Textitle & $-.06(-.26)$ & $.02(.97)$ & $.33(.18)$ & $-.66(2.12)$ & $-.23(-.05)$ & 1.99 & 1.51 \\
\hline \multirow{4}{*}{$\begin{array}{l}\text { Hong } \\
\text { Kong }\end{array}$} & Laws Intl. & $-.009(-.10)$ & $.02(.47)$ & $-.36(-.52)$ & $-.09(-.72)$ & $-1.34(-.81)$ & 1.99 & 0.71 \\
\hline & Novel Entp. & $.10(.68)$ & $0(0)$ & 1.59 (1.45) & $-.04(-.23)$ & $-3.03(-1.16)$ & 2.00 & 1.02 \\
\hline & Unisouth & $.02(.16)$ & $-.03(-.75)$ & $.26(.33)$ & $-.06(-.41)$ & $-.51(-.26)$ & 2.00 & 0.91 \\
\hline & Crocodile & $-.04(-.14)$ & $-.01(-.16)$ & $-.67(-.36)$ & $-.33(-1.04)$ & $-.25(-.06)$ & 1.88 & 1.08 \\
\hline
\end{tabular}


nificant. A depreciation of the Taiwanese currency seems to hurt Century, an Indian firm. The estimates for the Pakistani firms are statistically insignificant. Two out of the three firms from Thailand, viz., Thaitex and TRT gain from a depreciation of the baht. The sign on the third is negative but not significant. Thaitex is adversely affected by a depreciation of the Indian rupee. The results on Taiwan are by far the most consistent. All the three firms in the sample - Carnival, Rebar and Chung Textiles gain significantly from a depreciation of the home currency. A depreciation of the Pakistani cur rency seems to benefit the Taiwanese firm, Rebar, significantly, but the magnitude of the coefficient is almost zero. The only unexpected coefficient is that of the depreciation of the Hong Kong dollar on the equity of Century, an Indian firm. It is negative and significant, suggesting somewhat paradoxically that the Indian firm benefits from a depreciation of the Hong Kong dollar.

From Table 3, when individual firm equity values are aggregated in order to arrive at a measure of a country's share in total industry value, the first cell (row 1, column 1) indicates a significant redistribution of the same in favor of India due to nominal depreciations of its currency. The country that loses its share due to depreciations of the rupee is J apan. Indian share suf-

Table 3

Tea and Textile Industry Equity-Share Redistribution

\begin{tabular}{|c|c|c|c|c|c|c|c|}
\hline \multirow[b]{2}{*}{ Country } & \multicolumn{5}{|c|}{ Tea } & \multirow{2}{*}{$R^{2}$} & \multirow{2}{*}{ D.W. } \\
\hline & India & Kenya & Japan & UK & Sri Lanka & & \\
\hline India & $-.04\left(-3.34^{*}\right)$ & $-.023(-1.00)$ & $.01(.35)$ & $.02(1.12)$ & $.06(1.51)$ & 0.18 & 1.96 \\
\hline Kenya & .31 (1.19) & $-5.21(-.97)$ & $.03(.16)$ & $.16(.37)$ & $.63(.82)$ & 0.21 & 1.89 \\
\hline Japan & $.45(2.83 *)$ & $.40(1.38)$ & $-.18(-.6)$ & $-.28(-1.24)$ & $-.79(-1.7)$ & 0.16 & 2 \\
\hline \multirow[t]{3}{*}{ UK } & $-.03(-.26)$ & $00(.07)$ & $.08(.54)$ & $-.04(-.25)$ & $-.27(-.69)$ & 0.09 & 1.97 \\
\hline & \multicolumn{5}{|c|}{ Textiles } & \multirow{2}{*}{$R^{2}$} & \multirow{2}{*}{ D.W. } \\
\hline & India & Pakistan & Thailand & Taiwan & Hong Kong & & \\
\hline India & $-.25(-1.94)$ & $0(-.27)$ & $-.83(.9)$ & $.07(.48)$ & $-2.49(-1.11)$ & 0.22 & 1.98 \\
\hline Pakistan & $.01(-1.09)$ & $0(-4.84 *)$ & $-.02(-.03)$ & $.01(.13)$ & $-.59(2.84 *)$ & 0.09 & 2.09 \\
\hline Thailand & $.2(1.19)$ & $0(-.22)$ & $-1.59(-1.34)$ & $.12(-.59)$ & $2.84(.99)$ & 0.27 & 1.99 \\
\hline Taiwan & $-05(-.29)$ & $0(-1.5)$ & $-.33(-.22)$ & $-.67\left(-2.58^{*}\right)$ & $2.19(.62)$ & 0.25 & 1.98 \\
\hline Hong Kong & $.05(.72)$ & $0(.26)$ & $.04(.08)$ & $-.12(-1.3)$ & $.92(.-73)$ & 0.13 & 1.99 \\
\hline
\end{tabular}


fers due to depreciations of its geographically nearest competitor, Sri Lanka. In the Textile industry as well, depreciation of the Indian rupee leads to a significant redistribution of industry share in favor of the Indian exporters on the whole. The same is true for Taiwan.

Overall, the results seem to indicate that daily depreciations of the home currency vis-a-vis the dollar, are associated with a rise in the equity values (in dollars) of home exporting firms. Daily changes in the nominal exchange rates seem to play a significant role in redistributing industry equity shares as well. ${ }^{3}$ One of the main reasons behind the apparent difference of these results from the insignificant coefficients reported in Amihud [1994] may lie in the fact that the import contents of the Indian firms in the Tea and Textiles are negligible. Thus, this particular set of firms is free from possible exposure due to substantial import bills. The theoretical presumption regarding the sign of exposure is less ambiguous for these firms and arises mainly from the revenue channel rather than costs of production 〈Levi [1994]〉.

Following Amihud [1994], a separate set of regressions were run, using unanticipated changes in the exchange rates as independent variables. The model that generated unanticipated changes in the exchange rate is as follows.

$$
\ln \mathrm{E}_{\mathrm{t}}=\alpha+\beta \ln \mathrm{E}_{\mathrm{t}-1}+\varepsilon_{\mathrm{t}}
$$

Where $E_{t}$ denotes the current proportionate change in the exchange rate. The residuals from the above regression are taken as unanticipated changes in the exchange rate. Table $A$ in the appendix reports the results of this set of regressions. However, replacing the actual exchange rate changes with these residuals leads to no significant alterations in the previous estimates except that the F-statistics turn out to be generally less significant. Thus, for all the equations, the null hypotheses that the coefficients of unanticipated exchange rate changes are jointly zero look more plausible than that for anticipated changes. ${ }^{4}$

3. However, the F-statistics for the null hypothesis that all the coefficients are jointly non-zero, are not always significant.

4. Since the coefficients and their significance levels are almost the same in every case, I have not included these results in the paper for brevity. The F-statistics are generally smaller compared to Tables 1 and 2 . 
In the next section I focus attention on the devaluation of the Indian rupee in July 1991, and examine if it had any beneficial effect on the equity prices of the Indian firms.

\section{Devaluation of the Rupee: An Event Study}

Devaluations are distinct from daily changes in the exchange rate. The former involves an official announcement, a greater one-time proportional change, and, in the cur rent context, the usher of other liberalizing changes in a tightly controlled Indian economy. The devaluation of 1991 was thus an important economic "event" and the object of this section is to examine its information content.

Event studies assume that security markets are efficient and examine whether a particular announcement has "information content". The latter may be defined as observation of a statistically significant association between the announcement and the distribution of stock prices. Total prices or returns are ex post partitioned into two components using the market model. One of these components is perfectly correlated with the return on some market index while the other is both orthogonal to the market index and has a zero mean. The second component is referred to as the residual or abnormal return. The purpose of focusing on residual returns is to remove a confounding effect and thereby provide a (statistically) more powerful test for information content. Under weak conditions such an ex post partition of a random variable can always be achieved, and it does not involve the assumption that returns are "generated" by the market model.

The sample consists of 8 major exporting Indian firms in the Tea and Textile industries. The excess equity prices for each firm are generated using the market model proposed by Fama.

$$
\varepsilon_{\mathrm{it}}=\mathrm{R}_{\mathrm{it}}-\left(\alpha+\beta \mathrm{R}_{\mathrm{mt}}\right)
$$

where $\varepsilon_{i t}=$ the excess equity price for firm $\mathrm{i}$ on day $\mathrm{t}$,

$R_{\text {it }}=$ the equity price of firm $i$ for day $t$, and

$\mathrm{R}_{\mathrm{mt}}=$ the market index.

Two alternative versions of a market index are used. The N ew York Stock 
Exchange composite index and the National Stock index for India as reported in the Bombay Stock Exchange for day t. The parameters of the above equation are estimated over the period ED-120 to ED-20, where ED refers to the event day. The 20 days immediately before the event are excluded from the estimation period in order to remove any noise. The parameter estimates thus obtained are used to generate the excess equity prices over the event period ED-20 to ED +15 . Daily excess prices are aggregated to obtain average excess price $\left(\mathrm{AP}_{t}\right)$

$$
A P_{t}=1 / N \sum_{i=1}^{N} i t
$$

where $\mathrm{N}$ is the number of firms in the sample.

In efficient markets, the average excess prices should not be statistically different from zero. To test for that, the following statistic is used:

$$
\mathrm{TAP}_{\mathrm{t}}=A \mathrm{P}_{\mathrm{t}} / \sigma
$$

where $\sigma$ is the standard deviation of the average residuals and is calculated over days ED-120 to ED-20. If the average excess price is iid normal, then $\mathrm{TAP}_{\mathrm{t}}$ will conform to a student's t-distribution with 100 degrees of freedom. This procedure is consistent with that of Brown and Warner [1985] and takes into account the cross-section dependence in performance measures.

Before presenting the results it is worth noting the following points regarding the statistical properties of daily data. It is a well-documented fact that daily stock prices and excess stock prices are highly non-normal. The evidence generally suggests that distributions of daily returns and daily excess returns are fat-tailed relative to a normal distribution 〈F ama [1976] $\rangle$. However, Brown and Warner in a simulation-based approach were able to establish strongly that the mean excess return (and price) in a cross-section of securities converges to normality as the number of securities increases. Standard parametric tests for the significance of the mean excess return are well-specified. They further note that in samples of only 5 securities the tests typically have the appropriate probability of Type 1 error. Table 3 presents the values of the abnormal average returns (and the associated tratios), one using the New York Stock Exchange index and the other using the $N$ ational Stock Index of India, for the sample of 8 firms that were expect- 
ed to be affected by the devaluation. Table 3 also reports the same statistics for groups of firms that are relatively unexposed to the event, viz., the Bombay Stock Exchange average. It includes the stock prices of all the firms that are traded on the Bombay Stock Exchange, including the ones in our previous sample.

\section{A. Results from Event Study}

From Table 4 it may be seen that that there were no significantly abnormal excess returns for the population around the time of the devaluation. Abnormal excess returns are observed only for the sample of exporting firms. There were two devaluations with a gap of a day in J uly 1991. The second, probably because it was fully anticipated, did not generate any abnormal returns. The sum of the positive excess returns on ED-2 and ED are exactly of fset by negative excess returns on ED-3. Positive abnormal returns appeared again 14 days later.

Giddy [1974] used the event-study method to measure the effect of the devaluation of the dollar in the the 1970's on the stock prices of U.S. firms. $\mathrm{He}$ found a positive reaction to the devaluation by the market as a whole. However, the results for specific industries were mixed. In the present case, the opposite seems to hold true. The market as a whole shows no abnormal behavior, in either direction. Stock prices of exporting firms in the Tea and Textiles seem to react positively. As mentioned earlier, one reason behind some of the significant exchange rate coefficients may be that the industry under consideration has minimal import requirements. Thus, these firms have a better possibility of benefitting from the implications of a cheaper currency on the revenues earned from foreign sales. The positive reaction of the market as a whole, found by Giddy, may be due to economy-wide effects of changes in exchange rates, such as corporate tax rates. Such effects may have been absent in the Indian case, thus ruling out any significant reaction by the market as a whole. These other possible effects of exchange rate changes could be included in future analysis of currency exposure.

There are significant but offsetting movements in stock prices of the exporting firms in the immediate vicinity of the announcement, i.e., ED in 
Table 4. Significant positive excess returns reappear two weeks after the announcement. These findings lend themselves to a logical possibility such as the following. Rational investors may have perceived the devaluation as a nominal disturbance to (supposedly) the equilibrium terms of trade, and that the economy would soon return to its initial real equilibrium. Therefore, the price movements offset each other. ${ }^{5}$ Positive movements after two

Table 4

Behavior of Average Excess Price around the Devaluation

\begin{tabular}{|l|c|c|c|c|}
\hline \multirow{2}{*}{ Period } & \multicolumn{2}{|c|}{ Export Firms } & \multicolumn{2}{c|}{ All Firms } \\
\cline { 2 - 5 } & NYSE-based & NSE-based & NYSE-based & NSE-based \\
\hline ED-4 & $.02(.44)$ & $.02(.41)$ & $0(-.01)$ & $0(.00)$ \\
ED-3 & $-.24\left(-4.56^{*}\right)$ & $-.23\left(-4.31^{*}\right)$ & $-.01(-.2)$ & $0(.01)$ \\
ED-2 & $.14\left(2.62^{*}\right)$ & $.14\left(2.71^{*}\right)$ & $-.01(-.15)$ & $-.01(-.2)$ \\
ED-1 & $.02(.37)$ & $.02(.36)$ & $-.02(-.34)$ & $-.01(-.2)$ \\
ED & $.11\left(2.22^{*}\right)$ & $.12\left(2.31^{*}\right)$ & $.01(.2)$ & $.02(.4)$ \\
ED+1 & $-.01(-.15)$ & $-.01(-.14)$ & $-.01(-.09)$ & $0(.08)$ \\
ED & $0(.17)$ & $0(.18)$ & $-.01(-.27)$ & $-.02(-.38)$ \\
ED+1 & $-.01(-.15)$ & $-.01(.2)$ & $.04(.87)$ & $.04(.9)$ \\
ED+2 & $-.01(-.14)$ & $0(-.11)$ & $.01(.09)$ & $.02(.29)$ \\
ED+3 & $-.01(-.15)$ & $-.01(-.13)$ & $.03(.4)$ & $-.01(-.09)$ \\
ED+4 & $0(-.11)$ & $0(.00)$ & $-.01(-.22)$ & $-.02(-.42)$ \\
ED+5 & $.02(.3)$ & $.02(.33)$ & $.02(.36)$ & $0(.03)$ \\
ED+6 & $-.02(-.29)$ & $-.01(-.27)$ & $0(-.03)$ & $0(-.03)$ \\
ED+7 & $-.02(-.29)$ & $-.01(-.27)$ & $-.01(-.2)$ & $-.02(-.38)$ \\
ED+8 & $.02(.31)$ & $.02(.29)$ & $-.01(-.24)$ & $-.02(.28)$ \\
ED+9 & $0(.12)$ & $0(.09)$ & $.01(.27)$ & $.02(.41)$ \\
ED+10 & $-.02(-.34)$ & $-.02(-.31)$ & $-.04(.78)$ & $-.03(-.62)$ \\
ED+11 & $.02(.4)$ & $.02(.28)$ & $0(-.03)$ & $-.01(-.24)$ \\
ED+12 & $.03(.61)$ & $.03(.61)$ & $0(.00)$ & $.03(.62)$ \\
ED+13 & $.02(.23)$ & $.02(.3)$ & $-.01(-.2)$ & $0(-.01)$ \\
ED+14 & $.17\left(3.2^{*}\right)$ & $.15(2.99 *)$ & $-.02(-.37)$ & $-.02(-.37)$ \\
\hline
\end{tabular}

5. However, this interpretation can be subject to the criticism that given such perception, why would the stock prices have moved at all? 
weeks may be taken as evidence in favor of the credibility of the signal of sustained liberalization that may have been generated by the devaluation. For instance, when trade liberalization is preceded by a devaluation (which raises the buffer of foreign reserves) it may signal that the government will not reimpose trade restrictions even if there is a temporary loss of reserves due to jumps in imports after liberalization. Under this perception, a devaluation can trigger investment decisions appropriate for the ensuing regime, and lead to a rise in the stock prices of these firms. Thus, the beneficial effects of a devaluation will arise from "real" sources rather than the transient impact on the terms of trade at the stroke of a pen.

\section{Final Remarks}

Traditional analysis of devaluations are weighted with theory and evidence based on commodity markets with a relative neglect of financial markets.An uncontroversial link cannot be established between changes in prices (induced by devaluations) and trade flows, because the lag with which the latter respond is unknown and perhaps not even uniform for the hundreds of commodities that comprise the trade balance. It is proposed that due to their proven efficiency, stock markets are able to provide estimates of the true effects of devaluations within a framework that is theoretically more acceptable. Evidence from financial markets in developing countries has hardly been exploited, partly due to the difficulty of obtaining reliable data. This paper takes a step towards removing that obstacle in order to bring the financial markets of developing countries, especially India, to the forefront. In principle, the method simply invokes the efficiency property of financial markets. Thus, it is based on a theory that is less ambiguous than its commodity-market counterpart.

This paper emphasizes the need for disaggregated, or industry-wise analysis of the effects of exchange rate changes. Any conclusion arrived at by looking at the overall trade balance may be flawed because of the unknown speeds of price and quantity adjustments in the various commodity markets. The alternative method used here also calls for some strong information requirements on the composition of a firm's balance sheet, especially with regard to the import content of its products and the nature 
of tax liabilities. The redeeming feature about the latter variety of informational requirement is that it is a matter of availability of existing information in an organized fashion. Sophisticated dataset on stock markets are becoming increasingly common, even in emerging stock markets such as India. The speeds of adjustments of the various prices and quantities in commodity markets, on the other hand, remain largely as a matter of guesswork.

\section{Appendix}

Table A

Regressions Determining Unanticipated Exchange Rate Changes (Equation 3 in Text)

$$
\mathrm{ER}_{\mathrm{t}}=\alpha+\beta E \mathrm{R}_{\mathrm{t}-1}+\varepsilon_{\mathrm{t}}
$$

\begin{tabular}{|l|c|c|c|r|}
\hline Currency & $\alpha$ & $\beta$ & DW & F-Stat \\
\hline India & $-.001\left(-2.26^{*}\right)$ & $-.057(-.84)$ & 1.95 & .70 \\
Kenya & $-.001\left(-3.04^{*}\right)$ & $-.364\left(-5.75^{*}\right)$ & 1.95 & 33.12 \\
Japan & $00(00)$ & $-.292\left(-4.52^{*}\right)$ & 2.03 & 20.49 \\
U.K. & $00(00)$ & $.073(1.08)$ & 1.97 & 1.17 \\
Thailand & $00(00)$ & $-.049(-.73)$ & 2.00 & 0.53 \\
Hong Kong & $00(00)$ & $-.038(-.55)$ & 1.97 & 0.57 \\
Pakistan & $-.001(00)$ & $.66\left(20.29^{*}\right)$ & 2.16 & 412.05 \\
Taiwan & $00(00)$ & $-.051\left(-8.63^{*}\right)$ & 2.06 & 74.52 \\
\hline
\end{tabular}

\section{References}

Adler, M . and Dumas, B [1984], "Exposure to Cur rency Risk: Definition and M easurement," Financial M anagement, Summer; pp. 41-50. Adler, M . and Simon, D [1986], "Exchange Risk Surprises in International Portfolios," Journal of Por tfolio M anagement, W inter; pp. 44-53. Amihud, Yakov [1994], "Exchange Rates and Valuation of Equity Shares," in Amihud, Y. and Levich Richard M (eds) Exchange Rates and Corporate Performance, N ew York University Salomon Center, Irwin Professional Publishing, New York ISBN 1-55623-596-8. 
Brown, S. and Warner, J [1980], "M easuring Security Price Performance," Journal of Financial E conomics, September; pp. 205-258.

Edwards, S [1989], "Economic Adjustment and Exchange Rates in Developing Countries," The MIT Press.

Fama, E., Fisher, L., Jensen, M., and Roll, R. [1969], "The Adjustment of Stock Prices to New Information," International Economic Review, February; pp. 1-21.

Fama, E [1976], Foundation of Finance, New York: Basic Books.

Giddy, Ian [1974], "Devaluation, Revaluation and Stock M arket Prices," Ph.D. Disser tation, University of M ichigan.

Guha-K hasnobis, B [1995], "A Normative Analysis of the New Economic Policy of India with Emphasis on Her Exchange Rate Dynamics," Ph.D. Disser tation, University of Rochester.

Guha-Khasnobis, B [1996], "The Effect of Currency Depreciations when there are Produced M eans of Production," M anuscript, Indira Gandhi Institute of D evelopment Research.

Jones, R. W. and Corden, W. M. [1976], "D evaluation, Non-flexible Prices and the Trade Balance for a Small Country," Canadian Journal of Eco nomics; pp. 150-161.

Jorion, Phillipe [1990], "The Exchange Rate Exposure of U.S. M ultinationals," Journal of Business; pp. 331-345.

Levi, M aurice D [1994], "Exchange Rates and Valuation of Firms," in Amihud, Y. and Levich Richard M (eds) Exchange Rates and Corporate Per formance, New York University Salomon Center, Irwin Professional Publishing, New York ISB N 1-55623-596-8.

Luehrman, T [1987], "The Exchange Rate Exposure of a Global Competitor," Journal of International Business Studies, Vol 21, No. 2; pp. 225-242.

Miles, M . A [1978], Devaluation, the Trade Balance and the Balance of Pay ments, M arc Dekker, INC.

Stockman, A. C. [1987], "The Equilibrium Approach to Exchange Rates," Economic Review, Federal Reserve Bank of Richmond, M arch/ April. 